\title{
The Impact of International Aids on the Domestic Development in India: From the Aspects of Human and Economic Development
}

\author{
Chen Zheng, * \\ ${ }^{I}$ Shanghai University of International Economy and Business, Shanghai, Shanghai, China \\ ${ }^{*}$ Corresponding author. Email: $18045048 @$ suibe.edu.cn
}

\begin{abstract}
Contemporarily, India obtained a great amount of economic support from international organizations for the development of domestic infrastructure and upgrading the Indian economy, many of which achieved good results. In order to explore the impact of the international aids on India, the essay applies case study as its main research method, since India is a typical developing country, which can well represent others. Based on the analysis, in modern time, India government actively takes part in international organizations, especially the financial organizations, obtaining great amount of financial and technical support from them. International aids can make a difference to the impoverished areas to establish the infrastructure and then improve the life quality. Furthermore, through the case study of India, the essay hopes to have broader lessons for many other countries undergoing resemble problems and needs. In conclusion, the essay deepens the understanding of the function of the international organizations and aids, the real measurement, and effects of the international aids in India. Besides, the benefits that some developing countries can get from the globalization trend. Moreover, the essay can be useful to provide some political recommendations to the government of Global South, and experience to the international organizations who can propose international aids to the countries and regions that need external aids. There is also limitation of the evidences: some projects of India do not have detailed reports and statistics, and considering the length of this essay, not all projects can be analysed in detail. Besides, this essay only researches for the developing mode and results of India, while the suggestions for other countries still needs to check with real practice. Further studies can investigate the real feedback of Indian citizens who are benefited from the international aids and whose living situation are changed by these projects. These results shed light for a detailed analysis about the India's management and implement of international aids supported by latest data, and provide a mutual and effective model and exemplar for countries and regions needing international aids, helping them better employ such benefits.
\end{abstract}

Keywords: India, International Aids, Domestic Development, World Bank

\section{INTRODUCTION}

Nowadays, how Indian government plans, applies for and measures international aid from the international organizations remains a hot topic. Besides, the effects of these aids on the development of India society, especially the infrastructures, is also needed to be investigated. India has many successful projects in several international organizations like World bank and AIIB (The Asian Infrastructure Investment Bank), most of which focused on infrastructures like cleaning water, electricity, transport, agriculture, and education. Although there is much information about single projects of India, the research question of this essay is still puzzling and knotty because of lack of overall and systemic estimations of all the projects. India owns the second biggest population in the world and enormous GDP while it still has many domestic troubles needing external help to solve them. Hence, the question is unique and urgent, deserving comprehensive researches and approaches.

In the trend of globalization, the links between different countries are increasingly tight in multidimensions. Globalization may increase the trade between states and stimulate the manufacturing and service industry in an most aspects, which consequently boosts the economic growth [1]. Humanism and harmony 
are emphasized and prevailed around the world because a safe, healthy, and peaceful society is the foundation of further development. International organizations, states, business and even individuals all take part in global aid, donation, and voluntary causes for the sake of the security and life quality of citizens of every country. Various countries, especially developing countries and backward countries, have received such support. In 1980s, the former leader if China, Deng Xiaoping pointed that "Peace and development are the themes of the era" [2]. People across the world should make joint efforts to achieve these common targets of human beings.

This essay will focus on case study and document analysis. Document analysis is necessary and accessible because most of the information and producing process of the projects in World Bank and AIIB are authentic and public available. As for case study: typical, universal (it undergoes almost all problems that a developing country may meet).

The three reasons for choosing India as the research target are as follows. Firstly, India has received the largest number of the infrastructure projects. Secondly, Typical problem. As a big country, the problems in India are diverse, almost including most of the problems met by other developing countries. Therefore, lessons from the experience of India can have broader effects to other developing countries. Finally, India can set a good model for other countries because India has also been providing aids for the least developed countries.

This topic matters, because deeper knowledge about India, the region (south Asia/countries and regions surrounding the Indian Ocean) and even the whole world, especially developing countries. Furthermore, the thorough research in this topic can help change the world. The suggestions can be proposed to Indian government and the experience of India can be expanded to other countries, especially the least developed countries who need numerous aids most eagerly.

The essay is divided into several sections. After the introductions is a portray for India, examining the situation of its economic, human development as well as some social problems. Afterward, the essay will look at the development projects of India in international and reginal organizations. Then, the essay will then offer an analysis of India benefits from international aid, taking the transport projects from AIIB as examples. Furthermore, this essay will subsequently review Indian experience of international aids which can also applied by other Global South countries. Conclusion is the last part of the body of this report, which summarizes the whole research, making a foundation for further studies, and providing policy implications for the government of other countries and international organizations.

\section{THE SITUATION AND CHALLENGES OF CONTEMPORARY INDIA}

As an Asian country, India owns the second biggest population in the world. In 2021, the population of India hits 1.355 billion with fast increasing rate and extremely high density of population. Thanks for its enormous population and matured manufacturing system, the GDP of India in 2019 was about 2,871 billion, composing about $3.27 \%$ of the whole world [3].

India is one of the core centers for software, as the IT industry is the most famous and popular industry there. Additionally, corporations of developed countries always established their manufacture firms in India for lower labor force cost and huge market.

Moreover, this ancient country is deeply affected by religion, and is known as a religious museum. The influence of religion penetrates every part of its society and culture, playing a prominent role in the development of the country and live of majority Indians. About $83 \%$ of the population of India believes in Hinduism, the most prevalent and local religion in India.

Besides, the Caste system also sets many restrictions on Indians in which citizens are divides into several levels. People in Sudra, are taken as slaves who always serve as waiters and craftsman. However, girls in Untouchable, who are even inferior to Sudra, are not exposed to education, reflecting the severe gender inequality and poor education in India.

\subsection{Poverty and Economic Inequality}

As is illustrated in Figure 1, according to the OPHI (Oxford Poverty \& Human Development Initiative), even though the MPI of India is not as higher as many other developing countries, the disparity between its urban and rural areas is prominent. Nutrition and years of schooling are the biggest barriers to the battle of poverty in current India [4].

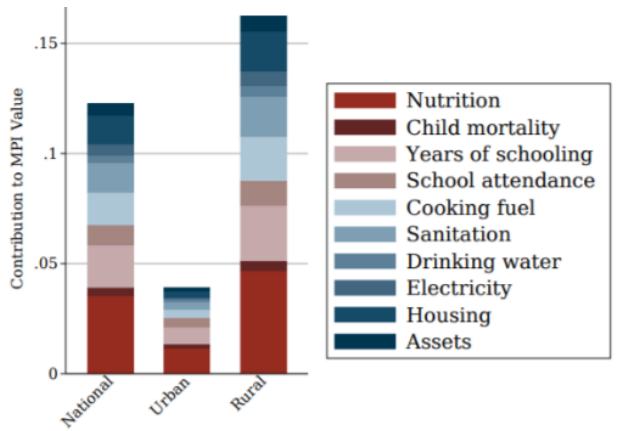

Figure 1 Indicator Contribution to MPI of India (year 2015-2016) [4]

The caste system in India plays a prominent role in the division of social classes and Hierarchy. Some people are born nobles, while some can only engage in low-paid jobs in their whole lives. This has led to the consolidation 
of classes, and has gradually widened the gap between rich and poor. In India, the proportion of poor people is larger. Thus, the MPI of rural areas of India still deserves some attention.

In 1991, India started its economic reforms to reduce government intervention in economic development, relax restrictions on the private economy and foreign investment, relax restrictions on import and export trade, reform the fiscal and taxation system and the banking financial system, and promote the gradual expansion of India's foreign economic relations. The sudden emergence of high-tech industries has promoted the accelerated growth of the Indian economy and the rise of construction [5]. Nevertheless, there are still many problems after India's economic reform. The technological progress and capital accumulation of India turn out to stimulate the economic inequality and income gap. This is due to the industrial structure and capitalists' exploitation of the proletariat, which is not conducive to eliminating poverty and narrowing the gap between the rich and the poor.

\subsection{Illegal Business}

It is notorious that India has several black industries exploring human rights, e.g., the commercial surrogacy. India legalized commercial surrogacy in 2002, and became the biggest surrogacy center of the world. Although this business was banned in 2015, the supply chain still exists in India, whose value can reach 2.8 million per year, and more than $80 \%$ of its customers came from abroad [6].

Many Indian women have low or no income whose lives are not guaranteed, i.e., they have to work as "surrogate mothers" under the heavy pressure from their families. Therefore, the prosperity of India's surrogacy and other black industries can be largely attributed to India's poverty and inefficient government regulation. Plenty of them not only violate human rights, but also disrupt marketing order.

\subsection{Poor Infrastructure and Corruption}

India has abundant resources and labor, but the construction of infrastructure needs further improvement. Until now, Indian public transportation, medical services, and financial institutions still cannot meet the needs of its residents. There are still many overloaded and dirty buses and trains in Indian stations, which often put passengers at risk.

Worse more, bribery and corruption influence India deeply, rooted in many fields, e.g., government, business, and education. In 1996, Hawala bribery in India shocked the world [7]. Although this scandal was exposed to the public and received a lot of criticism and condemnation, revealing the corruption of some Indian officials, it did not stop the bad situation. This builds some relationships between the regulations of Indian government and the interests of some consortia, making money interfere with the policy and causing social unfairness.

\section{INDIA IN INTERNATIONAL AND REGINAL ORGANIZATIONS}

Before the national independence of India in 1947 , the first president of India, Jawaharlal Nehru, acclaimed that "She (India) will either count for a great deal or not count at all", aiming to push India as a country of significant international status and the center of economy and politics of Indian Ocean region [8].

On account of its marvelous population and economic volume, the international status of India cannot be neglected. The diplomacy of India has a strong feature of mercantilism [9], taking economy as one of the most significant issues of its diplomatic work. It focuses on importing capital and advanced technology, and exporting India's goods and labor to overseas. Since stepping into modernization, India has joined various world organizations, such as United Nations, World Bank, AIIB, BRICS (Brazil, Russia, India, China, and South Africa), APEC (Asia-Pacific Economic Cooperation), and SCO (Shanghai Cooperation Organization).

Especially since the 21 st century, considering the increasing demands and imbalanced development of domestic economy, the Indian government has proactively applied for projects and sought help from these international organizations. In this way, the Indian government obtained abundant foreign funds, programs, technical support, and other useful resources.

\subsection{World Bank and India}

Under the Bretton Woods Charter of 1944 was the establishment of the International Bank for Reconstruction and Development (IBRD) which became the landmark of the new era of "development-withforeign-aid" [10]. One year later, IBRD and the International Development Association were merged as a new organization, the World Bank.

The World Bank was originally established to help European countries and Japan in the reconstruction after World War II. In addition, it also undertakes the task of assisting the economic development of countries in Africa, Asia, and Latin America. Its purpose is to provide loans and investment to member states to promote the balanced development of international trade. In November 1947, the World Bank became a specialized agency of the United Nations. Its main business is divided into two parts: financial products and services, and innovative knowledge sharing. According to the applicant, amount and purpose of fund application, financial products and services are mainly divided into 
general loan and non-loan assistance. Since its foundation, the World Bank has funded over 309.91 billion US dollars in 2,988 development projects, by the way of traditional loans, interest-free credits, and grants [11].

At the entrance of the headquarter of the World Bank in Washington, there is a slogan says, "Our dream is a world without poverty". The World Bank acts as one of the most vital resource, where the developing countries seek for credits of favorable conditions [12]. As an authentic founder of the World Bank, India has had a long history in the World Bank since 1945, so as to its history of receiving assistance from the World Bank. Although the financial fund from the World Bank under the policy and implementation of different regions has different effect and outcome, while the outcome in India was considered great and useful [13]. Until the August of 2021, India has 885 projects in the World Bank, ranking top among the countries with most projects and consequently being the biggest beneficiary [14].

\subsection{AIIB and India}

In October 2013, Chinese President Xi Jinping formally proposed the establishment of "Asian Infrastructure Investment Bank" (AIIB) during his visit to Southeast Asian countries, which has received positive response and support from many countries. AIIB began its operations in Beijing in January 2016 and have since grown to 103 approved members worldwide. It is a multilateral development bank whose mission is financing the Infrastructure for Tomorrow, infrastructure with sustainability at its core [15].

Once entering AIIB, Indian soon became the biggest borrower of this vagrant international bank [16]. Since 2017, 43 projects of India have been approved and implemented by AIIB, ranking the most among all member states [15]. These projects are mainly aimed at critical infrastructures construction in India, e.g., energy, transport, education, and financial institutions, thereby accelerating the process of poverty elimination and modernization of India. With the consistent economic reforms, the Indian government is bound to further deepen its economic diplomacy in order to promote a healthy external economic environment [17].

\section{INFRASTRUCTURE AND TWO EXAMPLES OF THE INTERNATIONAL AIDS PROJECTS IN INDIA}

As it reported in the annual report of the independent evaluation group (IEG) of the World Bank, "Infrastructure plays a key role in providing equal access to economic opportunities and social services" [18]. Obviously, infrastructure is important and can be seen as the foundation for India to solve many existing problems. The World Bank has helped various countries to develop infrastructure by giving financial aids and technological support.

\subsection{Transport}

As Table 1 lists, since 2017, India has proposed 16 projects of transportation construction to AIIB, accounting for more than one-third of Indian projects. Seven of them got approvement from AIIB, and funds and resources have been officially invested to start the construction, which is designed for rural development in India.

Table 1 Projects of Transport in AIIB Proposed by India since 2017 [19]

\begin{tabular}{ccc}
\hline $\begin{array}{c}\text { APPROVAL } \\
\text { YEAR }\end{array}$ & PROJECT NAME & $\begin{array}{c}\text { FINANCING } \\
\text { AMOUNT }\end{array}$ \\
\hline 2020 & India: Delhi-Meerut Regional & USD500 \\
& Rapid Transit System & million \\
2019 & India: Mumbai Urban Transport & USD500 \\
& Project - Phase III (MUTP) & million \\
2018 & India: Andhra Pradesh Rural & USD455 \\
& Roads & million \\
2018 & India: Madhya Pradesh Rural & USD140 \\
& Connectivity & million \\
2018 & India: OSE InvIT & USD50 million \\
2017 & India: Bangalore Metro Rail & USD335 \\
& Project - Line R6 & million \\
2017 & India: Gujarat Rural Roads & USD329 \\
& (MMGSY) & million \\
\hline
\end{tabular}

In April 2018, the Indian government submitted the project application, "India: Andhra Pradesh Rural Roads" to AIIB which is proposed to establish safe and convenient roads network for residents in Andhra Pradesh [20]. The improved road network allows Andhra Pradesh to be accessible to the broader external market, better education, and other public services, improving the regional economy and eliminating poverty.

AIIB invested 455 million US dollars in this project to build and upgrade more than 6,000 kilometers of allweather roads, connecting about 3,300 rural habitations in Andhra Pradesh. These roads promoted the connection between Andhra Pradesh, whose main industry is agriculture, and the other cities, expanding the transporting volume, and reducing the difficulty and hazard in transportation of agricultural products.

Besides, the all-weather roads are also expected to bring advanced health treatment and education. People in Andhra Pradesh can go to hospitals in big cities for treatment, and children are accessible to educational resources from other regions. Besides, the enrollment rate of Andhra Pradesh children, especially for girls, may encounter a significant increase in the future. 


\subsection{Energy}

Energy is of great importance to a country. On one hand, it is tightly correlated to the daily life of residents just as Fan Zhang, the senior economist at the World Bank, claimed that, "Power sector reforms should be a top priority, as few other reforms could quickly yield economic gains of a similar magnitude. If well designed, reforms will directly benefit the poor by increasing access, improving reliability and reducing cost and emissions" [21]. On the other hand, Energy consumption and economic growth are interdependent to each other, which means as a necessary infrastructure the sufficient and overall provided energy is a premise for improving economy evenly [1]. Power shortages is a disaster to economic output, with most industries and manufacturers depending on expensive and polluting diesel generators for back-up power supply in India [22].

In India, until 2017, about 178 million people still inaccessible to power and even lived in dark [21]. Connecting all of India's population to reliable electricity would dramatically increase the income of rural households and prevent nearly $\$ 23$ billion a year in business losses.

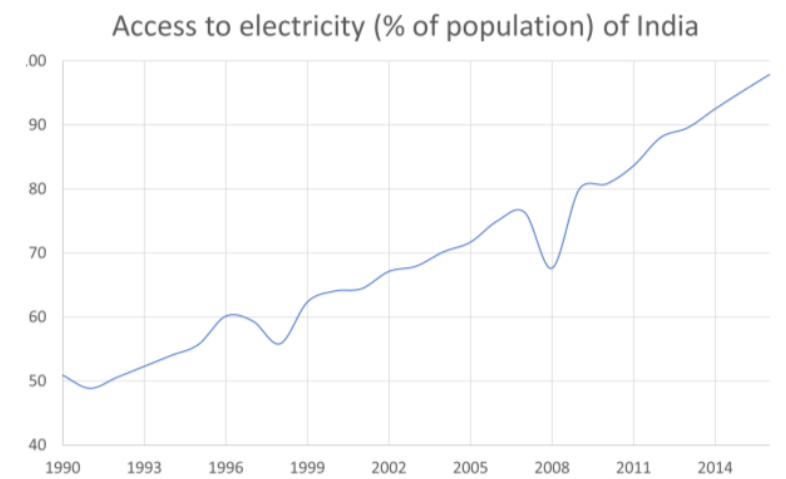

Figure 2. Access to Electricity (\% of Population) India (Year 1993-2019) [23]

The indicator, access to electricity (\% of population) of India, is the percentage of Indian population who are accessible to electricity. The data is collected from many sources including industry, national and international surveys, which is official and disinterested.

As illustrated in the Fig. 2, from the World Bank Data, since 1993, the accessibility of sustainable electricity for Indians has been increasing stably at a rather high speed. Although India underwent two drop of electricity access during the procession, in 2001 and 2011 respectively, it quickly recovered to the original developing level. In 2019 , this indicator has reached $97.815 \%$, which is a meritorious progress that really benefits the local citizens [23].

According to Table 2, after solving the basic problems of electricity supply, the projects in recent years of India in the World Bank underscore more on sustainable energy like solar and water energy for the more environmentally friendly and long-term development. Cutting the elimination of carbon-dioxide and manufacturing more clean energy by commercial ways are the main purposes of the new energy projects. Luckily, production and consumption of electricity from renewable energy are efficient for achieving carbon neutrality targets [24].

Table 2 Projects of Energy in the World Bank Proposed by India since 2017 [25]

\begin{tabular}{ccc}
\hline $\begin{array}{c}\text { APPROV } \\
\text { AL YEAR }\end{array}$ & PROJECT NAME & FINANCING \\
AMOUNT
\end{tabular}

In 2014, nearly 400 million Indian people lived without electricity, while in 2019, this number dropped to 200 million [22]. Those who could be exposed to electricity, continued to bear frequent disruptions [26]. To approach these poor situation, Indian Government proposed many projects focused on energy in the international organizations, especially the World Bank.

The lasting financial support from World Bank has helped India to enhance electricity producing capability, expand electricity transmission across the country's region. The new built $40,000 \mathrm{~km}$ power circuit during the Indian five-year program (2008-12), raising interregional electric power transfer capacity from 21 to 37 gigawatts, was also attributed to the efforts from the World Bank [22].

\section{SUGGESTIONS FOR INDIA AND OTHER DEVELOPING COUNTRIES}

At the meeting about strengthening the ability if LDCs (Least developed country) to defend national debt in 2019, Achim Steiner said, "At a time of growing financial volatility \& $40 \%$ of LDCs facing debt distress, strengthening resilience to debt vulnerability is a key priority" [27].

$40 \%$ of the LDCs and low-income countries have or are at a high risk of getting into debt distress, the other 
164 countries face extremely high risks, and the problems in sub-Saharan Africa are particularly disturbing.

What is worse, COVID-19, a catastrophe of all human beings, casts a shadow over the proceedings of the world in all aspects, disproportionately impacting vulnerable populations and revealing persistent inequalities by income, age, race, sex and geographic location. The pandemic has also debunked the huge gaps of health systems in different countries. weaker health systems risk jeopardizing hard-won health and development gains made in recent decades [28]. Therefore, as a positive exemplar who have the great amount of international aid and good reputation for ability and honesty to pay for the international debt, Indian has much experience deserves other countries to learn.

On the one hand, Indian government is very good at creating projects that it needs, which is also willing to actively seek for help from various international organizations. The Indian proposals are implemented in specific regions and projects, and most of them are in line with the sustainable development standards of international organizations and Indian economic policies. They act powerful roles in promoting the economic development of the India, especially in rural areas.

On the other hand, India actively participates in the affairs of many international organizations, actively seeks a higher international status. Moreover, it is willing to help other more backward countries build infrastructure and upgrade their economies.

India can provide other developing countries with experience in seeking and providing international assistance. Other global south countries can learn from Indian experience and actively look for more high-quality international aids to improve the domestic economy.

\section{CONCLUSION}

India keeps on seeking a higher international status and has actively participated in many international organizations and international aid. India has obtained a large amount of funds and technical support from international organizations such as the World Bank and the Asian Infrastructure Investment Bank for its own infrastructure construction, which has greatly promoted the development of the Indian economy, especially in rural areas.

The essay tried to explore the effects of the international aids on India. India is an active participant in international organizations and international aid. It has observed in recent years that India obtained a great amount of economic support from international organizations for the development of domestic infrastructure and upgrading the Indian economy, many of which achieved good results. The essay applies case study as its main research method, since India is a big country with great population and GDP, and many social problems including poverty (terrible gap between poor and rich), corruption, poor transport, and education, lacking drinking water and energy, while owning the greatest number of international aid projects in AIIB, being a typical developing country, which can well represent others. These results offer a guideline for most countries in need of international assistance, and encourages Indian government to maintain its advantage in employment of international aids.

\section{REFERENCES}

[1] Alex O. Acheampong, Elliot Boateng, Mary Amponsah \& Janet Dzator, 2021. Revisiting the economic growth-energy consumption nexus: Does globalization matter? . Energy Economics, vol.102.

[2] Gao Yi, 2012. History chose Deng Xiaoping. Retrieved from: http://cpc.people.com.cn/n1/2018/1023/c6911330356831.html

[3] World Bank,2021. GDP (current US\$) - India. Retrieved from: https://data.worldbank.org/indicator/NY.GDP.MK TP.CD?locations=IN

[4] Oxford Poverty \& Human Development Initiative, 2020. Global MPI Country Briefing 2020: India. Retrieved from: https://ophi.org.uk/wpcontent/uploads/CB_IND_2020.pdf

[5] Wen Fude, 2012. The progress and problems in Indian economic reforms. South Asian Studies Quarterly, no.148, pp.92-99.

[6] Subhash Sharma \& He Guosheng, 2021. Indian: A Surrogating Firm. World View, no.3.

[7] Toral Patel, 1998. Corrupt Practices in India. International and Comparative Law Journal

[8] Jawaharlal Nehru, 1944. Discovery of India. Beijing, World Knowledge Press, 1958 edition, p 57.

[9] Wang Wei, 2008. The feature of the economic diploma of India. Contemporary World, no.4, pp.5153.

[10] Vyuptakesh Sharan, 1989. The World Bank and India: An Appraisal of the Flow of Financial Resources. Sage journals, vol.23, no.4, pp. 430-443.

[11] World Bank, 2021. Global Overview of the Projects. Retrieved from: https://maps.worldbank.org/

[12] Hua Biyun, 1989. India: The Biggest Beneficiary in the World Bank. World Affairs, no.05, pp.14-15. 
[13] Ranganathan, V, 2003. World bank and India's economic development. Economic and Political Weekly, pp.236-241.

[14] World Bank, 2021. Projects on India. Retrieved from: https://projects.worldbank.org/en/projectsoperations/projectslist?countrycode_exact $=\mathrm{IN} \& \mathrm{os}=0$

[15] AIIB, 2021. Introduction of AIIB. Retrieved from: https://www.aiib.org/en/index.html

[16] China Bond, 2018. India is the largest borrower of the AIIB, no.3, pp.1.

[17] $\mathrm{Hu}$ Shichun, 1993. Appealing economic diplomacy of India. Global Review, no.2, p.15.

[18] IEG of World Bank, 2011. Lessons from World Bank Support to Infrastructure. Retrieved from: https://ieg.worldbankgroup.org/sites/default/files/D ata/reports/infrastructure_web.pdf

[19] AIIB, 2021. Projects of Transport in AIIB proposed by India since 2017. Retrieved from: https://www.aiib.org/en/projects/list/year/All/mem ber/India/sector/Transport/financing_type/All/statu s/All

[20] AIIB, 2018. India: Andhra Pradesh Rural Roads. Retrieved from: https://www.aiib.org/en/projects/details/2018/appro ved/India-Andhra-Pradesh-Rural-Roads.html

[21] The World Bank, 2018. Power Sector Distortions Cost India Billions. Retrieved from: https://www.worldbank.org/en/news/feature/2018/ $12 / 17 /$ new-report-power-sector-distortions-costindia-billions

[22] The World Bank, 2014. Sustainable Energy for All: Sector Results Profile. Retrieved from: https://www.worldbank.org/en/results/2013/04/10/s ustainable-energy-for-all-results-profile

[23] The World Bank, 2021. Access to electricity (\% of population) of India. Retrieved from: https://data.worldbank.org/indicator/EG.ELC.ACC S.ZS ? contextual $=$ default\&end $=2019 \&$ locations $=I$ N\&start $=1994 \&$ type $=$ shaded $\&$ view $=$ chart $\&$ year $=2$ 019

[24] Juan Lin, Yijuan Shen, Xin Li \& Amir Hasnaoui, 2021. BRICS carbon neutrality target: Measuring the impact of electricity production from renewable energy sources and globalization. Journal of Environmental Management, vol.298. Retrieved from:

https://www.sciencedirect.com/science/article/pii/S 030147972101522X?via\%3Dihub
[25] The World Bank, 2021. Projects about Energy of India. Retrieved from: https://projects.worldbank.org/en/projectsoperations/projectslist?countrycode_exact $=\mathrm{IN} \& \mathrm{os}=0$

[26] The World Bank, 2019. India Project Update: Grid Connected Rooftop Solar Photovoltaic Program. Retrieved from: https://documents1.worldbank.org/curated/en/1630 21467995349943/pdf/103245-PGID-P155007Revised-Appraisal-Box394862B-PUBLICDisclosed-2-11-2016.pdf

[27] The United Nations, 2019. UN: Heavy Debt Has Significant Influence on LDCs. Retrieved from: https://news.un.org/zh/story/2019/04/1032411

[28] World Health Organization, 2021. The impact of COVID-19 on global health goals. Retrieved from: https://www.who.int/news-room/spotlight/theimpact-of-covid-19-on-global-health-goals 